\title{
Autonomous Peasant Struggles and Left Arts of Government
}

Dr Robin Dunford, Lecturer in Globalisation and Contemporary War, University of Brighton

"This is an Accepted Manuscript of an article published by Taylor \& Francis in Third World Quarterly on 18/8/2015, available online

http://www.tandfonline.com/doi/full/10.1080/01436597.2015.1037388.

\section{Acknowledgements}

This paper has benefited from comments from Dr Alex Prichard, Professor Clive Barnett, and Professor Diane Perrons

\begin{abstract}
I argue that self-organisation cannot account for how grass roots struggles can pursue transnational political change. I develop an account of some "left arts of government" through which resistance is facilitated and organised without reintroducing oppressive and hierarchical forms of rule. I do so by focusing on the practices of autonomous peasant mobilisations. Land occupation movements facilitate the ability of people to engage in ongoing resistance on their own behalf. They organise resistance through horizontal communication and through transnational networks involving representative structures. Finally, peasant mobilisations engage with states and international institutions to solidify gains made.
\end{abstract}

\section{Key Words}

Resistance and Activism, Human Rights, Citizenship, Land Reform, Pastoralism and Peasants 


\section{Autonomous Peasant Struggles and Left Arts of Government}

Self-organisation has been heralded as a process enabling different struggles to develop into a counter-hegemonic globalisation without the need for deliberate forms of organisation that might undermine the autonomy of diverse struggles. ${ }^{1}$ Put differently, diverse, grass roots struggles are sometimes understood to coalesce to form a transnational, counterhegemonic movement without the need for conscious and deliberate organisational work performed by social movement activists. I argue that self-organisation and emergence cannot account for how grass roots struggles can pursue transnational political change. To this end, I develop an account of some "left arts of government" through which resistance is facilitated and organised without reintroducing oppressive and hierarchical forms of rule. I do so by focusing on the practices of autonomous peasant mobilisations. Land occupation movements, first, facilitate the ability of people to engage in ongoing resistance on their own behalf. Second, they organise resistance through horizontal communication and through transnational networks involving representative structures. Finally, peasant mobilisations engage with states and international institutions to solidify gains made. It is through these three arts of government that grass roots peasant mobilisations have been able to generate transnational political change.

As well as developing an account of the resistance strategies of grass roots and transnational autonomous peasant movements, I make a theoretical contribution in two areas. First, I take further James Ferguson's call, discussed in section 1, to develop understandings of left arts of government. ${ }^{2}$ Second, I highlight and attempt to overcome limitations in attempts, made by William Connolly, Eugene Holland, and Michael Hardt and Antonio Negri, to understand counter-hegemonic forms of globalisation. Connolly accounts for the emergence of a pluralist democratic assemblage through the self-organisation of micropolitical work on the self ${ }^{3}$, Holland suggests that grass roots alternatives to capitalism self-organise in a slow motion general strike ${ }^{4}$, and Hardt and Negri suggest that multiple grass-roots alternatives bring about revolutionary change through separate acts of exodus, 
or escape, from an exploitative empire. ${ }^{5}$ These three accounts all connect a micropolitics focused on small scale alternative forms of living and alternative ethical and political practices with an ontology of self-organisation in order to explain the possibility of largescale transnational change. In section two, after briefly introducing the transnational dynamics that dispossess peasants, I suggest that this jump between micropolitics and ontology occludes the difficult work involved in constructing counter-hegemonic forms of globalisation. My argument is developed by interspersing Connolly, Holland and Hardt and Negri's accounts of resistance with an analysis of the practices of the landless workers movement (MST) in Brazil and the transnational Via Campesina network of peasant struggles. In section 2, I first demonstrate how Connolly's focus on experimental selftransformation is inappropriate in contexts where forces of resistance need to be provoked and enabled. I then show the importance of deliberate attempts among peasant movements to, contra Holland and Hardt and Negri, communicate and organise, in a horizontal and democratic manner, in order to enable contestation at the transnational level at which multiple forms of peasant oppression take place. Finally, I highlight the importance of engaging with institutions, including states and international organisations, in order to solidify and institutionalise any political gains that they have made. The three arts of government developed through this focus on peasant mobilisations, based on mobilising forces to facilitate autonomy, collective organisation through horizontal exchanges and organisational structures, and engagement with institutions, offer a rich account of how a counter-hegemonic form of globalisation can be developed from multiple grass roots struggles.

\section{Section 1: Left Arts of Government and the Self-Organising Left}

Neoliberal globalisation 'both weakens and simultaneously activates the social forces of resistance'. ${ }^{6}$ Rising inequality, increasing precarity, and the loss of democratic voice through non-state actor involvement in governance provoke resistance, but also render 'traditional' forms of leftist organisation around a class of formal wage labourers and a welfarist government untenable. But instead of exploring alternative forms of organisation, the left,

Ferguson argues, has come to be 'defined by negation and disdain'. ${ }^{7}$ The left are 'always anti, never $\mathrm{pro}^{\prime}$, and thus have 'very little to propose by way of an alternative 'art of 
government", or an account of progressive ways of 'exercising power over others'. ${ }^{9}$ To this end, Ferguson proposes the development of left arts of government to rival neoliberal forms of governmentality. Ferguson proposes appropriating neoliberal reasoning for different ends. Neoliberal rationalities highlighting the empowerment of individuals through access to markets, for instance, might be appropriated to argue for a basic income grant given to empower people to look after themselves. But highlighting how neoliberal rationalities might be co-opted does not account for how a movement might be organised around such demands. Moreover, attending only to a range of particular alternatives, including cash transfers ${ }^{10}$, risks ignoring the ways in which transnational structures of oppression can stunt and limit experimental alternatives, as I shall demonstrate later in the case of autonomous peasant struggles, and leaves behind any hope for larger scale political change. Highlighting particular ways in which neoliberal rationality might be co-opted is therefore not sufficient to account for the possibility of a counter-hegemonic globalisation, or a 'globally organised project of transformation aimed at replacing the dominant (hegemonic) global regime'. ${ }^{11}$ What is needed is an account of how different forms of resistance can 'move beyond organisational silos devoted to single issues and particular constituencies' in order to form a mass movement. ${ }^{12}$

Connolly, Holland, and Hardt and Negri all use notions of self-organisation to account for the possibility of such a move toward large-scale resistance in a world in which 'traditional organisational forms based on unity, central leadership, and hierarchy are neither desirable nor effective' ${ }^{13}$ For Connolly, through 'experimental micropolitics on a variety of fronts' (ibid), individuals can separately contest different features of contemporary global capitalism. ${ }^{14}$ These separate actions may self-organise together and 'approach a tipping point at which a 'multidimensional pluralist assemblage' will emerge. ${ }^{15}$ For Holland, global neoliberal capitalism can be undermined through a 'slow motion general strike' in which diverse 'experimental alternatives' 'walk away from the existing order' in a piecemeal fashion. ${ }^{16}$ As they pursue alternative forms of provisioning, such as production cooperatives, they connect 'internally and immanently, from the bottom up' through the common effect they have in undercutting the dependence of global capitalism on exploitative labour relations. ${ }^{17}$ When enough 'experimental alternatives' exist (ibid), 'a 
critical mass or bifurcation point is reached', signalling a 'phase transition leading beyond capitalism' ${ }^{18}$ For Hardt and Negri, a counter-hegemonic 'multitude' emerges from a series of separate struggles, without a need for 'maker that stands behind the process' ${ }^{19}$ Separate struggles 'do not link horizontally' through 'communicative extension', nor do they seek to engage with or work through existing institutions. Because a global capitalist 'empire' depends on the multitude to produce value, be it in the form of goods or in the form of ideas that can be patented and sold, the multitude are able to attack the 'virtual centre' of empire, its core dependence on collective creation of value, by virtue of an 'exodus' from...existing political structures. ${ }^{20}$

Connolly, Holland, and Hardt and Negri thus all account for transnational forms of resistance by moving from a micropolitical account of experimental alternatives to an ontology of selforganisation. Self-organisation is not, I argue, sufficient to explain how grass roots alternatives can generate transnational social and political change. Rather, left arts of government, or forms of power through which resistance is facilitated and deliberately organised, are required in order to facilitate and connect forces of resistance. ${ }^{21}$ Struggles, including the peasant struggles that I discuss here, 'are inherently marked by issues that unite and divide, by tension and synergy'. ${ }^{22}$ These tensions cannot be ignored in the hope that different resisting groups can have common effects through their separate actions. As I shall demonstrate, the agrarian capitalist regime that generates common problems for peasants in diverse localities must be, can be, and is being resisted through deliberate arts of government. These arts of government develop forces of resistance, connect and organise diverse struggles at a transnational level, and engage with, with a view to transforming, existing institutions.

\section{Section 2: Peasant Resistance and Left Arts of Government}

Peasants, or smallholder producers and gatherers that make a living from the land and sea, have always faced multiple threats to their territory. But the 'agrarian capitalist paradigm' that has developed alongside the global spread of neoliberalism has generated transnational drivers of oppression. ${ }^{23}$ Agricultural subsidies in food export countries in the North combined with international free trade regimes enable the dumping of cheap goods. 'Local farmers cannot compete', and are 'driven off their land into deepening poverty'. ${ }^{24}$ 
The availability of cheap imported food, moreover, helps drive developmentalist agendas amongst states and international development agencies, which convert land used for smallholder production to the industrial production of 'a narrow range of agro-exports', generating mass displacement. ${ }^{25}$ Additionally, growing global demand for animal feed, driven by a doubling of global population size and 'fast rising meat consumption in industrialising countries', introduces further demands for the conversion of land to largescale ranching or animal feed production. ${ }^{26}$ All of these factors contribute to an agrarian capitalist paradigm based on an 'export-led, free trade based, industrial agriculture model of large farms'. ${ }^{27}$

These transnational dynamics of oppression amplified in light of the multiple crises of food, energy and climate that emerged in late 2007. The global food crisis saw record levels of hunger, leading 'to a wave of protests and anti-government riots in more than 60 countries $^{28}$, encouraging food-insecure governments that rely on imports to feed their populations, notably China and the Gulf states, 'to outsource their domestic food production by buying and/or leasing vast areas of farmland abroad'. ${ }^{29}$ The connections between this food crisis and the energy crisis introduce 'a sinister set of feedback loops' contributing to the wider development of an agrarian capitalist regime that undercuts peasants. ${ }^{30}$ Concern over the finitude of fossil fuels has led to rising demands for agrofuels for fuel security, stoking food crises, as large farmers take 'millions of acres of land out of production to grow biofuels', and generating new demand for land. For smallholder agriculturalists, this often results either in eviction or in dependence on precarious contracts to produce biofuels. ${ }^{31}$ Responses to the energy and climate crisis, moreover, have resulted in new environmental tools including carbon cap and trade programmes and reducing emissions from Deforestation and degradation. ${ }^{32}$ NGOs including the World Land rust, Cool Earth, and the WildLands have purchased 'hundreds of thousands of hectares of so-called empty land globally'. ${ }^{33}$ Moreover, 'exclusionary conservation' has resulted in the displacement of '14-24 million people in Africa' alone, as large areas of land are purchased for the purposes of nature conservation and ecotourism. ${ }^{34}$ Finally, the resultant increase in the value of land ensures that land is a strong a candidate for speculative forms of investment, with investors and private equity funds, including pension funds from US universities, acquiring land. ${ }^{35}$ 
This new demand for land has generated a global land rush. ${ }^{36}$ World Bank figures suggest that from October 2008 to August 2009, approximately 56 million hectares of cultivable land were transferred; up from an average of 4 million hectares per year before $2008 .{ }^{37}$ The fuel and energy crisis, brought about in part by the energy intensive nature of agrarian capitalist production, thus introduces self-amplifying trends that place further demand on 'so-called marginal, empty and available land across the globe ${ }^{38}$. This land is already used for livelihood activities including small scale farming and pastoralism. Land grabbing, then, operates as a form of accumulation via dispossession, depriving peasant populations of 'an important means of producing for their own survival', potentially forcing them 'into wage labour in order to sustain themselves' ${ }^{39}$

But these transnational dynamics of oppression are being contested. In multiple localities peasants have mobilised in movements like the MST, the federation of Indonesian peasant unions and the South African Landless People's Movement to directly occupy and produce on land, seeking to reclaim territory that they have lost and (re)gain the ability to engage in smallholder forms of production. ${ }^{40}$ At a transnational level, la Via Campesina brings together millions of farmers from 164 peasant organisations across 73 countries and five continents in common acts of protest and advocacy. ${ }^{41}$ । focus on these practices of resistance to develop understandings of left arts of government. I shall explore three elements of peasant resistance by contrasting them with three features of the self-organising resistance discussed by Connolly, Holland, and Hardt and Negri. First, I shall suggest that Connolly's experimental individual role performances are of limited relevance to grass roots land occupations, which instead exercise power to facilitate and organise forces of resistance. I then claim that Holland and Hardt and Negri's account of the non-communicative connection of multiple struggles fails to account for the more conscious forms of organisation that are crucial in enabling grass-roots alternatives to contest transnational sources of oppression. Finally, I contrast Hardt and Negri's account of resistance as exodus with the way in which peasant mobilisations engage with institutions in order to institutionalise and defend gains made. It is not through the self-organised coalescence of their diverse struggles, but through arts of government that facilitate forces of resistance, involve communicative forms of organisation, and engage with institutions, that grass roots peasant mobilisations have had effects at a large-scale, transnational level. 


\section{(i): Facilitating Resistance}

Connolly's proposals for developing a democratic assemblage of transnational resistance focus on 'experimental micropolitics' that shift 'some of our own role performances'. ${ }^{42}$ 'The initial focus is on changing the ethos of consumption' ${ }^{43}$ One might 'frequent stores that offer food based on sustainable processes', 'buy a hybrid', or 'put your retirement account into investments supporting sustainable energy'. ${ }^{44}$ These changes 'make a difference on their own', but they also 'help to set preconditions for constituency participation in more robust political movements' ${ }^{45}$ At this stage, there has been no need to form collective organisations that involve structures of government through which members are organised. It is at this stage that Connolly proceeds to 'condense some of the steps involved' to get to a time when the multidimensional pluralist assemblage in which you have now begun to participate approaches a tipping point' ${ }^{46}$ This assemblage self-organises and self-amplifies to constitute a larger scale political movement, generating an 'event' 'as if from nowhere' in which 'a many-fronted social movement', acting 'at multiple sites', is formed. ${ }^{47}$

The steps that are 'condensed' in Connolly's move from an ethics of experimental selftransformation to an ontology of self-organisation occlude important questions relating to the government of movements, and hide the work done by people engaged in resistance. This is not to say that specific, micropolitical interventions are not important; as I shall indicate later, a focus on micropolitical relations within the movement may help strengthen the MST. But it is to say that such interventions are not sufficient, and that even the ability to engage in micropolitical work on the self can, at times, require arts of government that foster forces of resistance. Despite Connolly's proclamation that his specific suggestions, designed for the 'constituencies who are most apt to read', his book, 'could easily be adjusted to a broader array', they seem to depend heavily on the privilege of being able to make ethical consumption choices. ${ }^{48}$ Such individual forms of action are not open to many peasants engaged in struggles against dispossession. MST occupations, for instance, typically begin by 'reaching out to excluded and impoverished segments of Brazilian society', including peasants, urban slum dwellers, urban homeless people, and people with a history of drug abuse. ${ }^{49}$ These individuals and families are unaware of legal avenues they can pursue, have little choice over which consumption practices to engage in, and, despite being aware of their oppression, are not necessarily aware of the broader structures that drive it. 
It is here that we meet a first left art of government in peasant mobilisations. The MST have helped collective forces by producing relatively autonomous communities that can provide materially and engage in ongoing resistance for themselves. Once recruited, the individuals and families that sign up for an occupation are moved to temporary rural encampments. The encampment, which can last from a matter of months to over 5 years, is a "key step in forging new people'. ${ }^{50}$ In the encampments, 'people learn to live cooperatively' and receive training in literacy, farming skills, and the administration of co-operatives. The encampments also 'promote the politicisation of' and 'facilitate mobilisation' by their members. ${ }^{51}$ 'Previously isolated individuals' come together to collectively learn about the broader structures that work to oppress them. ${ }^{52}$ Furthermore, this political education teaches settlers 'how to negotiate bureaucracy through collective action to obtain...agricultural supports' including land, credit, and technical assistance. ${ }^{53}$ It is through these learning processes that the MST have been able to lower abandonment rates, encourage ongoing mobilisation and protest even after members have obtained a plot of land in a settlement, and ensure food production is of a high quality and avoids the environmentally destructive methods for which the MST criticise agro-industries. ${ }^{54}$ Land occupations, in short, do not emerge 'as if from nowhere'. ${ }^{55}$ They are not 'autonomous, grass-roots based, civil society and social movements that rhizomatically and spontaneously cohere together' into a counter-hegemonic form of globalisation. ${ }^{56}$ Instead, they involve arts of government that facilitate and organise forces by developing the knowledge, skills, and identities that enable grass roots alternatives to agro-industry and foster ongoing contestation.

That is not, though, to say that everyday, micropolitical practice is not important. Indeed, reflection on the everyday politics of encampments indicates areas in which movement practices could be improved further. Despite a strong commitment to gender equality, the MST place strong on a model of family farming. In some cases, this focus has produced encampments that are a 'men's world'. ${ }^{57}$ Members are expected to remain on the encampment site in order to engage in the training and community building discussed earlier, but as the temporary encampments offer more limited prospects for growing sufficient food, members often remain dependent on a wage from external labour. Wageearning is possible for dual-parent families, who can keep one member on the encampment 
site as another seeks work externally, but is particularly difficult for lone female parents, one of whom has indicated that in the encampment, "life is harder for a woman with no man' $^{58}$ Feelings of 'lack of support and solidarity...abandonment' are sometimes magnified as other movement members deem women without men 'as a threat to their own marital relationship'. ${ }^{59}$ In this instance, movement members have some ability to alter their everyday practices and attitudes to offer more support for single female members, whilst an internal focus on movement practices might enable the development of a set of rules more friendly to single women.

\section{(ii) The Communicative Extension and Organisation of Resistance}

Left arts of government are not unique to the MST. The Federation of Indonesian Peasant Unions also engage in 'member training focused on the agrarian reform struggle'. ${ }^{60}$ Alberto Gomez Flores, the national coordinator for the national union of autonomous regional farmer organisations in Mexico, has noted that 'people at the grassroots need to be trained and informed in order to be fully committed and engaged in the struggle' ${ }^{61}$ Via Campesina work to develop the skills of various leaders involved in diverse peasant organisations. Elizabeth Mpofu, chairperson of the Zimbabwe smallholder organic farmers forum, said that Via Campesina 'has given me the courage that as a woman I can do it...through training, attending conferences and workshops, and participating in campaigns, I am able to understand our issues and how we should fight and organise our struggles'. ${ }^{62}$ But these synergies are not instances of different 'small' and 'scattered' forms of resistance that might codify through a common 'exodus' from the wage-labour relations that sustain capital. ${ }^{63}$ Nor do they arise without the need to link horizontally through 'communicative extension'. ${ }^{64}$ Instead, they result from left arts of government that work to spread the movement, develop unities, and construct forms of organisation that enable grass roots voices to contest the transnational sources of their oppression.

Grassroots alternatives are particularly vulnerable when they remain small and scattered. As discussed earlier, transnational dynamics underpin the rising value of land and the dumping of cheap agricultural goods, threatening the ability of peasants to maintain alternative smallholder spaces. Moreover, the autonomy that peasants gain through land occupations and collective learning processes is often relative; producers sometimes require start up 
credit, which can force them back into the 'imperative of competition' as 'they are compelled to find successful monetary activities to pay back their loans' ${ }^{65}$ Some families on MST settlements have 'sought salvation in the bittersweet promises of the sugar industry' by signing contracts that lock them in to biofuel production, thus restoring their dependence on fluctuating sugarcane markets. ${ }^{66}$ The imperative of competition thus threatens to re-interpolate peasants into markets, rendering them dependent on capitalist relations of exchange and potentially driving the very dominance of corporations and spread of biofuels that threaten grass-roots alternatives elsewhere. These pressures faced by 'food sovereignty islands in a neoliberal ocean' ${ }^{67}$ indicate that Holland is wrong to say that 'the slow motion general strike avoids... the extraordinary recuperative capacities of capital. ${ }^{68}$ Instead, the continual closure of alternative spaces undermines the possibility of a 'slow, piecemeal withdrawal'. ${ }^{69}$ Grassroots struggles, then, must be 'tied to both nationwide and transnational solutions. ${ }^{70}$

To this end, autonomous peasant movements have worked to extend their struggles beyond particular land occupations by developing arts of government that foster the horizontal spread of movements, through the development of common identities, analyses, and demands, and by forming organisational structures that enable peasant voices to be heard at a transnational level. The horizontal nature of the communication through which the movement is spread, combined with the constant attempt to mitigate against the introduction of new forms of oppression and hierarchy in larger scale organisational structures, mean that these practices can be characterised as left arts of government.

Whilst the MST is, in part, spread through the steering work of leaders, the movement is also spread in a horizontal manner. 'Any given encampment is always linked to another which will be formed', with participants in previous settlements 'teaching the newly encamped the technologies involved in setting up and organising the encampment form' ${ }^{71}$ Those that have substantial experience and are most heavily involved in the 'collective activities for the common welfare of all', be it day to day camp work or protests, marches and struggles, help set up new settlements. ${ }^{72}$ This organisational work ensures that knowledge and practices can spread 'from the ground up', in the words of one member. ${ }^{73}$ Whilst the MST have fostered the regional spread of the movement, they nonetheless acknowledge that, 'challenged by the new power of agribusiness, we need to build alliances 
among all peasant movements' ${ }^{74}$ The threats that undermine smallholder production are transnational in scope, meaning that, to survive, peasants must 'build unity to fight back across international borders'. ${ }^{75}$

It is for this reason that la Via Campesina was formed. Via Campesina did not just emerge spontaneously in a dramatic, self-organising event. Rather, it was formed through a series of meetings amongst farmers' representatives from four continents in 1993. Now, Via Campesina brings together 164 local and national organisations in 73 countries, with member organisations representing constituencies as diverse as small dairy farmers in Germany, rice farmers in South Korea, liberal environmentalists in the Global North, pastoralists and fisherfolk, and landless peasants. These groups have diverging interests that had previously kept them apart. Landless peasants might desire agrarian reform in order to gain plots of land, pastoralists may want free access to land desired by landless peasants, whilst liberal environmentalists may want to ensure that fishing, farming and grazing practices are subject to regulations ensuring sustainability. Such interests do not simply cohere together in light of common attempts at to escape wage-labour relations. Instead, arts of government are required to construct a common movement from these diverse constituencies.

The left arts of government developed by la Via Campesina involve a 'bottom up, not a top down process' bringing together the 'thousands' of 'local struggles' which 'already existed' through the construction of a common peasant identity, a common frame of analysis, and a common demand for food sovereignty. ${ }^{76} \mathrm{~A}$ common peasant identity is established through a broad definition of peasants as those that 'work the land themselves' through 'small-scale forms of organising labour'. ${ }^{77}$ This broad definition pulls together the diverse constituencies that partake in the movement, from those involved in small scale 'agriculture, cattle-raising, pastoralism, handicrafts-related to agriculture', through landless households involved in fishing, crafts and services, to hunters and gatherers, and peasants practising shifting cultivation. ${ }^{78}$ The identity of this wide grouping is reinforced by a common analysis of the agrarian capitalist regime that works to oppress the above groups. This regime, as discussed above, places great pressure on land, generating enclosures and conservation practices that simultaneously clear peasants from land, prevent pastoralists, hunter-gatherers and fisherfolk from living from previously common goods, and introduce self-amplifying 
dynamics that degrade land and introduce climactic uncertainties that threaten those living from the land. Moreover, the cheap imports that undercut producers in the South are based on decreasing prices paid to farmers in the North and on subsidies that prioritise large farms at the expense of smaller family farms, thus 'creating the objective basis for international struggle between peasants in the South and family farmers in the North' ${ }^{79}$

As well as articulating and organising this new peasant identity through the common analysis of a threat, Via Campesina also unites peasants behind a common demand for food sovereignty. Food sovereignty is the right of peoples to 'produce our own food in our own territory'. ${ }^{80}$ Food sovereignty goes beyond demanding a right to food or food security, which is compatible with the provision of food to the needy through industrial forms of agriculture. Food sovereignty also proposes that peasants maintain autonomy by producing their own food on their own territory. The term 'territory', rather than land, is important, having been emphasised following debates between different groups that constitute la Via Campesina at the 2006 land, territory and dignity forum in Porto Alegre. Whilst smallholder agriculturalists, family farmers, and land reform movements like the MST have typically demanded land, pastoralists and fisherfolk secure their autonomy through a connection instead to a wider territory across which they roam. Thinking in terms of territory thus ensures that the distribution of land to peasants does not undermine the rights of pastoralists to seasonal grazing areas, or of fisherfolk to fishing waters. ${ }^{81}$ Finally, by defining food sovereignty as the 'right of peoples to healthy and culturally appropriate food produced through ecologically sound and sustainable methods', Via Campesina are able to incorporate the concerns of liberal environmentalists within the movement. ${ }^{82}$ Via Campesina point to the fact that smallholder production produces ' 70 percent of the food consumed by humanity, despite the fact that peasants probably only hold a quarter of all farm land', and highlight the sustainable and resilient nature of agro-ecological production, contrasting this with the agrarian capitalist regime that involves vast energy expenditure in the form of mechanised inputs, food miles, and the growth of grain for livestock feed. ${ }^{83}$ This enables Via Campesina to suggest that a model of food sovereignty based on 'peasant agriculture can not only feed the world, it can also cool the planet' ${ }^{84}$

The development, through ongoing debate and discussion, of this common identity, analysis, and demand is reflective of the way in which la Via Campesina operates as an 
'arena of action' ${ }^{85}$ The International Conference, which meets roughly every four years, operates as the movements highest decision making body, and sees delegates from the diverse grass roots organisations that form la Via Campesina shape general principles and broad campaigns through consensus where possible, and democratically, after a process of participatory discussion, dialogue and consultation where not. ${ }^{86}$ The impetus thus comes from grass roots peasant organisations themselves, with the transnational Via Campesina space enabling them to develop a collective analysis internally through exchanges of ideas and experiences. Consequently, the common bond uniting Via Campesina is not a unity imposed from the top down, be it by movement leaders or by the 'many NGOs...acting on behalf of the peasants'. ${ }^{87}$ Indeed, in order to maintain autonomy, la Via Campesina does not permit external interference from NGOs or governments in its internal decisions. ${ }^{88}$ This ensures that peasants themselves can 'elbow their way' to the table 'wherever key debates or negotiations take place that affect the future of rural communities', taking a 'seat at the table in their own name...with the clear message that we are here and we can speak for ourselves'. ${ }^{89}$ Moreover, the common identity and agenda is pursued not only through discussion and deliberation, but through 'numerous means of communication'. 90 'All la Via Campesina meetings', for instance, begin with a shared ceremony or performance, known as a mistica, that builds solidarity amongst peasants through the use of imagery and symbols including seeds, soil, and water. According to a North American farm leader, the mistica 'are very important to create a sense of cohesiveness among people from such diverse and different cultures who do not speak common languages'. ${ }^{91}$ It is these labour intensive forms of community organising, and not abstract dynamics of self-organisation, that foster the development of common identities, analyses, and demands from the bottom up.

Between these assemblies, ongoing work is performed through representative movement operating through forms of organisation that remain horizontal insofar as they continually attempt to challenge inequalities. In an attempt to counter ongoing gender-based hierarchies, the International Co-ordinating Commission (ICC), the body which ensures that the principles and campaigns decided at the conference are adhered to, elects two representatives from each of the 9 regions that form la Via Campesina, at least one of which is female. Female assemblies take place before major events, which, according to one 
participant, give women a space to 'make themselves heard', 'validate...experiences' and give women 'confidence to occupy our rightful spaces effectively'. ${ }^{92}$ More recently, it was decided that each continent will nominate a youth representative to be part of the ICC in an attempt to counter hierarchies based on age. ${ }^{93}$ Finally, to help ensure that geographical hierarchies do not emerge, the international secretariat moves every four years, moving from Belgium, to Honduras, then Indonesia and, in 2013, to Zimbabwe. All leadership structures, then, are rotating and collective, and involve diverse gendered, youth, and geographical presence in a continued attempt to counter any emerging hierarchies.

This development of a common identity, analysis, and demand, undertaken through shared spaces for communication and performance, and furthered through representative structures, all suggest that diverse, grass roots peasant struggles do not self-organise by undercutting the dependence on wage-labour that sustains capitalism. Nor do they leap directly to the 'virtual centre' of an Empire that exploits them without any need to 'link horizontally' through 'communicative extension'. ${ }^{94}$ Rather, it is through multiple forms of communication, horizontal extension, and representative structures that grass roots struggles are able to contest transnational structures that generate ongoing oppression. Once again, arts of government are needed to extend, unite, and organise multiple struggles. These arts of government constitute left arts of government by virtue of the horizontal and open exchanges through which the movement spreads, by virtue of the continued attempt to maintain the autonomy of those involved, and by virtue of the constant attempts to mitigate against emerging hierarchies within organisational structures. That is not to say, though, that these left arts of government do not involve some forms of power and exclusion. Rather, the importance of developing a coherent identity and demand that can operate at a transnational level does involve ruling out certain visions. As Bina Agarwal has noted, there is a potential conflict between Via Campesina's commitment to producing one's own food in a sustainable manner and the democratic choices of farmers. 'Farm households...may choose options that are contrary to this vision' of sustainable, smallholder production, meaning that 'the programmes identified...by global movements' may conflict with the 'democratic freedoms of individuals' ${ }^{95}$ Agarwal highlights preferences, amongst some farmers in India, for planting non-food cash crops to sell, and to purchase cheap, potentially imported food, rather than grow it themselves. ${ }^{96}$ 
Whilst such farmers should not be restricted in making these choices, if my analysis of the importance of arts of government that bind and organise the movement is correct, it may be that the food sovereignty movement, to ensure their ongoing unity against a food regime that instils growing dependency on agro-exports and on the purchase of cash crops, have to maintain the centrality of their commitment to self-sufficient, autonomous production. This would mean that they could offer support and voice to, and strive to improve the conditions and contexts of, farmers who seek to engage in environmentally friendly, autonomous production. But they would potentially have to emphasise that this sustainability and autonomy is central to their vision, and stop short of helping people exit such farming or replace it with the production of cash crops, even if they express a desire to do so. This is to say that where there is a clash between the democratic choice of farmers and the vision of sustainable and autonomous smallholder production that has given so much strength to the MST and la Via Campesina, it may be that the exercise of a choice to exit sustainable, autonomous production is also a choice that places farmers outside of the Via Campesina network.

\section{(iii) Engagement with Institutions}

Like Holland, Hardt and Negri understand resistance in terms of 'exodus', or the 'withdrawal of collaboration' from existing political structures. ${ }^{97}$ 'The multitude' that drives resistance 'has no interest in taking control of the state apparatuses', 'not even in order to direct them to other ends'. ${ }^{98}$ Autonomous peasant struggles, though, reveal the significance of engagement and collaboration with institutions in order to divert them to other ends, indicating that a counter-hegemonic form of globalisation will involve engagement with institutions.

Though, as discussed earlier, MST occupations constitute relatively autonomous communities, they nonetheless look to engage with existing institutions. Once they have 'set their own priorities and determine[d] the ways to reach them' in assemblies, MST occupiers negotiate with existing institutions and elite actors. ${ }^{99}$ With the help of in house legal serves', 'exchanges with the radical legal provision', and sympathetic members of the government and the judiciary, they pursue legal avenues of negotiation with the state, calling on article 184 of the Brazilian constitution, which suggests that the government 
expropriate rural property that is not performing a social function. ${ }^{100}$ This constitutional principle is rarely used to expropriate land without occupations taking place, but the government have sometimes responded to the pressure of occupations by expropriating the occupied property or by exchanging it for land of equal value. Similarly, the MST work with the National Institute for Colonisation and Agrarian Reform (INCRA), the federal agency responsible for implementing land reform in Brazil. INCRA, according to its employees, 'can only attend insufficiently to its beneficiaries' on the basis of a limited administrative capacity. ${ }^{101}$ Thus, when faced with demands from land occupation movements, they sometimes use the occupation to facilitate land reform from below. In Paraiba, Northeast Brazil, for instance, one INCRA employee describes how INCRA deliver baskets of food to the occupiers, 'sign the accounting forms', 'authorise the list of people present', and leave this information with appropriate officers. ${ }^{102}$

By seeking state resources and support and implanting them within their relatively autonomous communities, the MST simultaneously engage in a form of exodus, through which they produce grassroots alternatives and provide for themselves, and engage with institutions. The MST have had particular success through this combination of factors ${ }^{103}$, enabling them to settle approximately two million members in 'government-funded land reform settlements or...temporary encampments'. ${ }^{104}$ Moreover, by having their land occupations legalised or regularised, the occupations gain a degree of protection from attempts, by landowners, to forcibly evict them, and are no longer easy to remove in pursuit of new projects that use customary land tenure or illegal and paralegal occupation status to force peasants from the land. By engaging with and making demands on existing institutions, the MST are therefore able to render their ongoing, existing alternatives more secure, facilitating the survival of alternative spaces of resistance.

This art of government which involves entrenching existing gains through engagement with institutions, though, depends either on a supportive government, or on forcing the hand of less supportive governments through contentious activity. Recent years have seen a slow down in government support for land reform. Though the MST has links with provides electoral support for the ruling Partido dos Trabalhadores (PT), the party has not pursued effective land reform. Rather, the PT is pursuing a neo-developmentalist agenda with a threefold effect on land reform. First, unproductive land has been increasingly in demand 
for large-scale agro-industry, generating a squeeze on the unproductive land traditionally targeted by the MST. Second, a new state corporatism is protecting the interest of agribusiness and 'increasing the clout of the most powerful national economic and political groups' in Brazil; interests typically hostile to land reform. ${ }^{105}$ Finally, with the developmentalist agenda in part used to attempt to raise the lot of the disadvantaged, through a 60 percent rise in minimum wages and the Bolsa Familia programme of cash transfers to disadvantaged Brazilian families, it has proved harder to encourage people to undertake the risks associated with land occupations. In this regard, the kind of cash transfer discussed by Ferguson, whilst helpful in raising the lot of the disadvantaged, may also be a hindrance to the structural reforms required for a counter-hegemonic globalisation, highlighting once more why left arts of government must go beyond specific co-optations of neoliberal rationality and toward the facilitation and organisation of counter-hegemonic resistance movements.

Under Lula, this neo-developmentalist agenda did not lead to a slow down in land reform, with rates remaining similar to those under the Cardoso government; a government toward which the MST adopted a more contentious attitude. But since 2011 under Rousseff's presidency, land reform has come to a standstill, with 2013, according to MST national coordinating body member João Paulo Rodrigues Chaves, being 'the worst year ever for agrarian reform, ${ }^{106}$ with just 159 families settled across the country. ${ }^{107}$ In light of this new government agenda, 'INCRA has reversed its policy of establishing workers settlements to resolve conflict' ${ }^{108}$ In the context of expectations of land reform under the PT not being met, some movement members in the states of Pernambuco and Parana have expressed concern regarding a 'co-option' of social movement agendas. ${ }^{109}$ In this period, moreover, there has been a decline in the number of land occupations, even as demonstrations have been on the rise. ${ }^{110}$ It may be, then, that engagement with institutions and attempts to force their hand through protests asking for land reform have been given too strong an emphasis in light of expected support from the PT. Given the reluctance of the PT to engage in land reform, an escalation in attempts to directly take land, and thus combine engagement with forms of exodus, may be required.

Though la Via Campesina pursue food sovereignty, which prioritises the ability of people to provide food for themselves on their own territory, they nonetheless engage with 
sympathetic governments and international institutions. Despite maintaining a confrontational stance towards the international financial institutions perceived to be the key tools of the neoliberal, corporate food regime that they oppose, Via Campesina negotiate and collaborate with potentially supportive states and with the United Nations. This collaboration has had some effect; states including Ecuador, Bolivia, Nepal, and Venezuela, 'in alliance or under the pressure of peasant movements, have initiated efforts to recognise this right' to food sovereignty in national laws or constitutions and translate it into policy, whilst the UN Human Rights Committee have adopted a resolution on the promotion of the human rights of peasants. ${ }^{111}$ Even if this engagement does result in a declaration and later a convention on the rights of peasants it remains a 'strategic vision for social mobilisation around these rights', rather than something that protects peasants of its own accord. ${ }^{112}$ Nonetheless, these institutionalised rights would give continued hope to grassroots struggles, and provide further resources that can be used in ongoing struggles for food sovereignty.

In sum, autonomous peasant movements operating at both grass roots and transnational levels do not self-organise spontaneously. Rather, their emergence and organisation involves left arts of government. First, contra Connolly's focus on experimental work on the self, autonomous peasant movements have worked to facilitate resistance, developing the skills and knowledge that enable members to engage autonomously in the creation and maintenance of ongoing grass-roots alternatives and in ongoing contestation. Second, autonomous peasant mobilisations do not coalesce in a non-communicative manner according to self-organising dynamics that see them escape the wage labour relations that sustain capitalism. Instead, they sustain challenges to transnational forms of dispossession through arts of government involving horizontal communication, attempts to construct common identities, analyses and demands, and through the creation of representative, institutional structures that attempt to respect autonomy and counter hierarchies. Third, autonomous peasant movements have not withdrawn fully from collaboration with states and existing institutions. Rather, they have developed arts of government that involve selective engagement with existing institutions, enabling them to solidify existing gains and generate resources for ongoing mobilisation.

\section{Conclusion}


I have focused on practices of autonomous peasant resistance to develop understandings of the left arts of government that enable grass roots forms of resistance to pursue transnational political change and contribute to a counter-hegemonic form of globalisation. First, I claimed that Ferguson's account of left arts of government as particular co-options of neoliberal rationality loses sight of the forms of contention required to generate large-scale political change. I then indicated how Connolly, Holland and Hardt and Negri use notions of self-organisation to account for the emergence of a counter-hegemonic form of globalisation from multiple experimental and grass roots alternatives. In so doing, they sidestep questions of how diverse struggles might be facilitated and organised. I built this argument by focusing on autonomous peasant movements operating at both grass roots and transnational scales. First, I explored the MST's practices of political education to suggest that Connolly's micropolitical role-experimentation is not possible in many cases, and that the development of experimental alternatives can require arts of government that facilitate resistance. Second, contra Hardt and Negri and Holland, I claimed that counterhegemonic struggles require arts of government that work to spread, connect and organise struggles. To this end, I focused on the horizontal, communicative extension and organisation pursued by the MST and la Via Campesina. Finally, I suggested, contra accounts of resistance as exodus, that peasant mobilisations have engaged with institutions in order to solidify existing gains, as demonstrated in the MST's attempt to legalise their occupations and in Via Campesina's attempt to institutionalise rights to food sovereignty.

Three left arts of government arise from this focus on autonomous peasant struggles. First, left arts of government help forces of resistance, not with the aim of enabling these forces to gain a better position within existing unequal and exploitative structures, but in order to foster their autonomy and enable them to engage in ongoing resistance. Second, left arts of government involve the horizontal and bottom-up spread, communicative extension, and organisation of movements, whilst constantly mitigating against the re-introduction of hierarchies. Third, left arts of government involve selective engagement with institutions, using constitutional declarations and sympathies amongst elite agents within institutions to institutionalise and solidify existing gains. These are by no means the only possible left arts of government, nor are they without potential problems. But the combination of these methods provides a rich account of how grass roots resistance can develop into a counter- 
hegemonic form of globalisation that can pursue and generate transnational social and political change. By facilitating and organising grass roots alternatives, peasants mobilisations have been able to make a real difference to the lives of those involved in the occupation and demonstrate that alternatives to agrarian capitalism are possible. By communicating horizontally, these grass-roots alternatives have united behind a common identity, analysis and demand, enabling them to understand, contest, and provide an alternative to the transnational structures that generate their ongoing oppression. Finally, by engaging with institutions, peasants have been able to solidify existing gains by having existing occupations legalised, by instituting food sovereignty principles in national constitutions and, if their advocacy within the UN is successful, by creating new peasant rights to food sovereignty. As well as offering a rich account of how grass roots resistance might contribute to a counter-hegemonic glonalisation, this account of the left arts of government developed within real, existing struggles draws attention to the extraordinary work involved in movement building; work which is occluded by accounts suggesting that major acts of resistance self-organise and emerge 'spontaneously', as if from nowhere.

\section{Bibliography}

Agarwal, Bina. "Food Sovereignty, Food Security and Democratic Choice", Journal of Peasant Studies 41, no. 6 (2014): 1247-1268.

Albuquerque, L.F. 2013 is the Worst Year for Agrarian Reform, Friends of the MST, available at http://www.mstbrazil.org/news/2013-worst-year-agrarian-reform\%E2\%80\%9D-saysjo\%C3\%A3o-paulo-rodrigues-chaves, 2013.

Altieri, M.A., and V.M Toledo. "The Agroecological Revolution in Latin America", Journal of Peasant Studies 38, no: 3 (2011): 587-612.

Baletti, Brenda, T.M. Johnson, and Wendy Wolford. "Late Mobilization", Journal of Agrarian Change 8, no.2-3 (2008): 290-314.

Borras Jr, S.M. "The Politics of Transnational Agrarian Movements", Development and Change 41, no. 5 (2010): 771-803.

Borras Jr, S.M., and J.C. Franco, "Global Land Grabbing and Political Reactions from Below", Third World Quarterly 34, no. 9 (2013): 1723-1747.

Caldeira, Rute. "The Failed Marriage Between Women and the Landless Peopl's Movement (MST) in Brazil", Journal of International Women's Studies 10, no. 4 (2009): 237-258.

Carter, Miguel (2014) Authoritarian Legacies, Democracy and Popular Resistance in the Brazilian Countryside', Presentation, available at http://www.norlarnet.uio.no/pdf/events/2014/from-coup/carter.pdf, accessed on 04 February 2015. 
Claeys, Priscilla. "The Creation of New Rights by the Food Sovereignty Movement", Sociology 46, no. 5 (2012): 844-860.

Connolly, William. The Fragility of Things, London: Duke University Press, 2013.

Dunford, Robin. "Human Rights and Collective Emancipation: The Politics of Food Sovereignty", Review of International Studies 41, no. 2 (2015): 239-261

Edelman, Marc, C. Oya and S.M. Borras Jr (2013) "Global Land Grabs: Historical Processes, Theoretical and Methodological Implications and Current Trajectories", Third World Quarterly 34:9, 1517-1531.

Evans, Peter. "Is an Alternative Globalization Possible", Politics \& Society 36 no. 2 (2008): 271-305.

Ferguson, James. "The Uses of Neoliberalism", Antipode, 41 no. 1, (2010): 166-184.

Ferguson, James. "Toward a Left Art of Government", History of the Human Sciences 24, no. 4 (2011): 61-68.

Fernandes, B.M, C.A. Welch and E.C. Gonçalves. "Agrofuel policies in Brazil", Journal of Peasant Studies, 37, no. 4 (2010): 793-819.

Gills, B.K., and Kevin Gray. "People Power in the Era of Global Crisis: Rebellion, Resistance, and Liberation", Third World Quarterly 33, no. 2 (2012): 205-224.

Gürcan, E.C. "Cuban Agriculture and Food Sovereignty", Latin American Perspectives, 41, no.4 (2014): 129-146.

Gomez Flores, Alberto. "Interview", 226-9 in Holt-Giménez, Eric (ed) (2010) Linking Farmers' Movements for Advocacy and Practice", Journal of Peasant Studies, 37, no.1 (2010): 203236.

Hardt, Michael, and Antonio Negri. CommonWealth, London: Harvard University Press, 2009.

Hardt, Michael, and Antonio Negri. Empire, London: Harvard University Press, 2000.

Holland, Eugene. Nomad Citizenship, Minneapolis: University of Minnesota Press, 2011.

Hollander, Gail. "Power is Sweet: Sugarcane in the Global Ethanol Assemblage", Journal of Peasant Studies, 37, no. 4 (2010): 699-721.

Confederacao Nacional das Associacoes dos Servidores do INCRA (2006), INCRA working group paper MP/SRH/no 1. 574.

Khan, G.A. "Pluralisation: an Alternative to Hegemony", British Journal of Politics and International Relations 10, no. 2 (2008): 194-209.

Kelly, A.B. "Conservation Practice as Primitive Accumulation", Journal of Peasant Studies, 38, no. 4 (2011): 683-701.

Kiersey, N. J. “Occupy Dame Street as Slow Motion General Strike?” Global Discourse 4, no. 2-3, (2014): 143-158.

Kröger, Markus. Contentious Agency and Natural Resource Politics, London: Routeledge, 2013.

Kröger, Markus. "Neo-Mercantilist Capitalism and Post-2008 Cleavages in Economic Decision-Making Power in Brazil", Third World Quarterly 33, no. 5, (2012): 887-901.

Loera, N.R. "'Encampment time': an Anthropological Analysis of the Land Occupations in Brazil", Journal of Peasant Studies, 37, no.2 (2010): 285-318.

Martinez-Torres, Elena, and Peter Rosset. "La Via Campesina: the Birth and Evolution of a Transnational Social Movement", Journal of Peasant Studies 37, no. 1 (2010): 149-175. 
Meszaros, George. "The MST and the Rule of Law in Brazil", Law, Social Justice and Global Development 1, no. 1 (2007): 1-24.

Mpofu, Elizabeth "Testimony", in Rosset, Peter (ed). "Grassroots Voices: Rethinking Agrarian Reform" Journal of peasant Studies, 40, no.4, 722-775.

MST Informa. Seventeen Years After the Massacre, the Attack on Land Reform Continues, Friends of the MST, available at http://www.mstbrazil.org/news/seventeen-years-aftermassacre-attack-land-reform-continues, 2013.

Rosset, Peter. "Food Sovereignty and Alternative Paradigms to Confront Land Grabbing and the Food and Climate Crisis", Development 54, no. 1 (2011): 21-30.

Rosset, Peter (ed). "Re-Thinking Agrarian Reform, Land and Territory in La Via Campesina", Journal of Peasant Studies, 40, no. 4 (2013): 721-775.

Sauer, Sergio. "Rural Social Movements and their Historical Contribution for Building Democracy in Brazil", Transnational Institute, available at http://www.tni.org/archives/sauer_ruralmovementsbrazil, 2008 .

Vergara-Camus, Leandro. "The Politics of the MST", Latin American Perspectives 36, no. 4 (2009): 178-191.

Vergara-Camus, Leandro. "The Legacy of Social Conflicts over Property Rights in Rural Brazil and Mexico", Journal of Peasant Studies 39, no. 5, (2012): 1133-1158.

Via Campesina. Annual Report 2013, available at http://viacampesina.org/downloads/pdf/en/EN-annual-report-2013.pdf, 2014.

Via Campesina. Food Sovereignty: a Future Without Hunger, available at

http://www.voiceoftheturtle.org/library/1996\%20Declaration\%20of\%20Food\%20Sovereignt y.pdf, 1996.

Via Campesina. Nyéléni Declaration on Food Sovereignty, 2007. Reprinted in Journal of Peasant Studies, 36, no.3 (2009): 673-676.

Via Campesina. Small Scale Sustainable Farmers are Cooling Down the Earth, available at http://viacampesina.org/downloads/pdf/en/EN-paper5.pdf, 2009.

Weis, Tony. "The Meat of the Global Food Crisis", Journal of Peasant Studies 40, no. 1 (2013): 65-85.

White, B., S.M. Borras Jr,, Ruth Hall, lan Scoones, and Wendy Wolford. "The New Enclosures", Journal of Peasant Studies 39, no. 3-4 (2012): 619-647.

Wiebe, Nettie. Women of la Via Campesina, available at http://viacampesina.org/downloads/pdf/openbooks/EN-01.pdf, 2013.

Wittman, Hannah. "Interview with Paul Nicholson", Journal of Peasant Studies 36, no. 3 (2009): 676-682.

Wittman, Hannah. "Reframing Agrarian Citizenship", Journal of Rural Studies 25, no. 1 (2009): 120-130, p 125.

Wolford, Wendy. "Participatory Democracy by Default", Journal of Peasant Studies 37, no. 1 (2010): 91-109.

World Bank. Rising Global Interest in Farmland, Washington DC: World Bank, (2010).

Zoomers, Annelies. "Globalisation and the Foreignisation of Space", Journal of Peasant Studies 37, no. 2 (2010): 429-447. 
${ }^{1}$ Connolly, The Fragility of Things; Hardt and Negri, CommonWealth; Holland, Nomad Citizenship.

${ }^{2}$ Ferguson, "Left Art of Government".

${ }^{3}$ Connolly, The Fragility of Things.

${ }^{4}$ Holland, Nomad Citizenship.

${ }^{5}$ Hardt and Negri, Empire.

${ }^{6}$ Gills and Gray, "People Power", 207.

${ }^{7}$ Ferguson, "The Uses of Neoliberalism”, 166.

${ }^{8} \mathrm{Ibid}$.

${ }^{9}$ Ferguson, "Left Art of Government", 62.

${ }^{10}$ Ibid.

${ }^{11}$ Evans, “Alternative Globalization”, 272.

${ }^{12}$ Ibid.

${ }^{13}$ Hardt and Negri, Empire, 166.

${ }^{14}$ Connolly, The Fragility of Things, 97.

${ }^{15}$ Ibid., 188.

${ }^{16}$ Holland, Nomad Citizenship, 98; 140.

${ }^{17}$ Ibid., 21; 140.

${ }^{18}$ Ibid., 170.

${ }^{19}$ Hardt and Negri, CommonWealth, 173.

${ }^{20}$ Hardt and Negri, Empire, 58; 204.

${ }^{21}$ Kröger, Contentious Agency, p 152 makes a parallel argument against Polanyian notions of the inevitability of a counter-movement to oppression. Movements must, Kroger argues, 'construct the right strategies and link them' to generate contentious agency.

${ }^{22}$ Borras Jr and Franco, “Global Land Grabbing”, 1737.

${ }^{23}$ Fernandes, Welch and Gonçalves, "Agrofuel Policies in Brazil”, 794.

${ }^{24}$ Martinez-Torres and Rosset "La Via Campesina", 162.

${ }^{25}$ Weis, "Meat", 73.

${ }^{26}$ Ibid., p 66.

${ }^{27}$ Altieri and Toledo, "Agroecological Revolution”, 607.

${ }^{28}$ White et al., "The New Enclosures", 627.

${ }^{29}$ Zoomers "Foreignisation of Space", 434.

${ }^{30}$ Hollander, "Power is Sweet", 700.

${ }^{31}$ Altieri and Toledo, "Agroecological Revolution", 589.

${ }^{32}$ White et al., "The New Enclosures", 629.

${ }^{33}$ Ibid.

${ }^{34}$ Kelly, "Conservation Practice”, 696-7.

${ }^{35}$ White et al., "The New Enclosures", p 629.

${ }^{36}$ Edelman, Oya, and Borras Jr. "Global land grabs".

${ }^{37}$ World Bank. Rising Interest, xiv.

${ }^{38}$ White et al, "The New Enclosures", 631; see also World Bank, Rising Interest.

${ }^{39}$ Kelly, "Conservation Practice”, 685-686.

${ }^{40}$ Rosset, "Re-thinking Agrarian Reform"; Baletti et al., "Late Mobilization".

${ }^{41}$ Via Campesina Annual Report 2013.

${ }^{42}$ Connolly, The Fragility of Things, 38.

${ }^{43}$ Ibid., 12. 
${ }^{44}$ Ibid., 187.

45 Ibid., 184.

46 Ibid.

${ }^{47}$ Ibid., 190-192.

${ }^{48}$ Ibid., 185.

49 Rosset, "Food Sovereignty”, 24.

${ }^{50}$ Ibid.

${ }^{51}$ Vergara-Camus, "Politics of the MST", 179.

${ }^{52}$ Rosset, "Food Sovereignty" p 25.

${ }^{53}$ Wittman, "Reframing Agrarian Citizenship”, 125.

${ }^{54}$ Rosset, "Re-thinking Agrarian Reform”, 728; Kröger, Contentious Agency, 62.

${ }^{55}$ Connolly, The Fragility of Things, 190.

${ }^{56}$ Khan, "Pluralisation”, 201.

${ }^{57}$ Caldeira (2009) "Failed Marriage”, 239.

${ }^{58}$ Encampment member, interviewed in Ibid., p 240.

${ }^{59}$ Ibid., p 240; p 249.

${ }^{60}$ Lubis, in Rosset, "Re-thinking Agrarian Reform ", 756.

${ }^{61}$ Gomez Flores, “Interview”, 226.

${ }^{62}$ Mpofu, “Testimony”, 769.

${ }^{63}$ Holland, Nomad Citizenship, 149; 156.

${ }^{64}$ Hardt and Negri, Empire, 58.

${ }^{65}$ Vergara-Camus "Social Conflicts”, 1150.

${ }^{66}$ Fernandes et al, “Agrofuel Policies in Brazil”, 801.

${ }^{67}$ Via Campesina activist, interviewed in Claeys, "New rights”, 854.

${ }^{68}$ Holland, Nomad Citizenship, 156.

${ }^{69}$ Kiersey “Occupy Dame Street”, 13.

${ }^{70}$ Gürcan, "Cuban Agriculture”, 144; see also Dunford, "Human Rights"

${ }^{71}$ Loera, "Encampment Time”, 290.

${ }^{72}$ Internal Rules of the Terra sem Males and Irma Alberta Encampments, 2003, cited in Ibid., 297.

${ }^{73}$ Edesmaria, interviewed in Loera, "Encampment time”, 306.

${ }^{74}$ MST, in Rosset, "Re-thinking agrarian reform”, 754.

${ }^{75}$ Rosset, "Re-thinking agrarian reform”, 723.

${ }^{76}$ Peasant Leader, interviewed in Martinez-Torres and Rosset, "La Via Campesina”, 166.

${ }^{77}$ Via Campesina, Sustainable Farmers, 6.

${ }^{78}$ Ibid.

${ }^{79}$ Rosset, "Re-thinking Agrarian Reform”, 723.

${ }^{80}$ Via Campesina, Future Without Hunger.

${ }^{81}$ Rosset, "Re-thinking Agrarian Reform”, 724.

${ }^{82}$ Via Campesina, Nyéléni, 673.

${ }^{83}$ Via Campesina, Annual Report 2013, 42.

${ }^{84}$ Via Campesina, Sustainable Farmers, 21.

${ }^{85}$ Borras Jr., "Transnational Agrarian Movements ”, 779.

${ }^{86}$ Via Campesina, Annual Report 2013, 4.

${ }^{87}$ Wilson Campos, Costa Rican activist, cited in Borras Jr. "Transnational Agrarian Movements”, 785.

${ }^{88}$ Martinez-Torres and Rosset, “La Via Campesina”, 157.

${ }^{89}$ Ibid.

${ }^{90}$ Gomez Flores, “Interview”, 226.

${ }^{91}$ Interviewed in Martinez Torres and Rosset, "La Via Campesina", 164.

${ }^{92}$ Wiebe, Women, 4. 
${ }^{93}$ Via Campesina, Annual report.

${ }^{94}$ Hardt and Negri, Empire, 58.

${ }^{95}$ Agarwal, "Democratic Choice", 1249.

${ }^{96}$ Ibid., 1256-9.

${ }^{97}$ Hardt and Negri, CommonWealth, 368.

${ }^{98}$ Ibid., 355.

${ }^{99}$ Vergara-Camus, "Politics", 185.

${ }^{100}$ Meszaros, "Rule of Law”, 9; 11.

${ }^{101}$ INCRA, "Working Group Paper”.

102 INCRA employee, interviewed in Wolford, "Participatory Democracy”, 99.

${ }^{103}$ Kröger, Contentious Agency.

${ }^{104}$ Baletti et al., “Late Mobilization”, 284.

${ }^{105}$ Kröger, "Neo-Mercantilist Capitalism” 888.

${ }^{106}$ Interviewed in Albuquerque, Worst Year.

${ }^{107}$ Carter, Authoritarian Legacies, 19-20 provides recent figures on numbers of agrarian reforms per year.

${ }^{108}$ MST Informa, Seventeen Years.

${ }^{109}$ Interviewed in Sauer, "Rural Social Movements", 21.

${ }^{110}$ Carter, Authoritarian Legacies, 31.

${ }^{111}$ Claeys, "New Rights”, 852.

${ }^{112}$ P. Nicholson, interviewed in Wittman, “Interview”, 679. 